\section{INSIDE THE CELL}

International Annual Review of Cytology

Vol. 20. Edited by G. H. Bourne and J. F. Danielli, Fp. xvi +380 . (New York: Academic Press, Inc.; London: Academic Press, Inc. (London), Ltd., 1966.) $136 s$.

THE combined efforts of electron microscopists and biochemists have recently led to the view that both the cristae of mitochondria and the grana of chloroplasts consist of arrays of particles which behave as multimolocular biochemical units for electron transport and phosphorylation. The review by $R$. B. Park traces the developmont of the concept of the quantasome as a macromolecular photosynthetic unit about $200 \AA$ in diameter arranged in an orderly array within the grana membranes of chloroplasts. Light-induced changes in chloroplast volume and structure are described by $\mathrm{L}$. Packer and P. Siegenthaler. 'The review by A. H. Maddy dcmonstrates that for the plasma-membrane the biomolecular leaflet of lipid model, proposed about thirty years ago by Harvoy and Danielli, is still a most useful concept. It is favoured by permeability and electrical measurements, chemical analysis and olectron microscopy. Yet the biological properties of the membrane indicate that it must be more complex than is suggested by the classical model. There are three reviews of different aspocts of mammalian physiology: the concentrations of potassium and sodium ions in the brain (H. Hillman), the triggering of ovulation by coitus in the rat (C. Aron, G. Asch and $J$. Roos) and the fine structure and histochemistry of prostatic glands in relation to sex hormones (D. Brandes). The latter two reviows aro well illustrated. J. T. Bagnara describes and illustrates the non-melanophore pigment colls of amphibians and fish, and suggests practical definitions for the terms "xanthophore", "erythrophore" and "iridophore". Finally, the enzymology of the cerebellum is reviewed by L. Arvy. Cytologists and cell biologists may profit from these eight scholarly reviews in the course of which 1,154 reforences are quoted. G. G. Selman

\section{ASPECTS OF CULTURE}

Cells and Tissues in Culture: Methods, Biology and Physiology

Vol. 3. Edited by E. N. Willmer. Pp. xvi +826. (London: Academic Press, Inc. (London), Ltd.; New York : Academic Press, Inc., 1966.) 1898.; \$29.

I HAVE to confess a prejudice against compilations of articles on distantly related aspects of a very broad field. Willmer, however, has done an extraordinarily good job of editing the chree volumes of Cells and Tissues in Culture and must be congratulated on coping so resolutely and succossfully with a daunting task. This third volume, which completes the trilogy, deals with some applications of tissue culture and some special techniques.

The chapters on applications are concerned with fibrogonesis, radiobiology, virology, immunology, pharmacology and research in plant developmental biology and phytopathology. Sylvia Fitton-Jackson is responsible for the interesting chapter on fibrogenesis. The article on the use of tissue culture in radiobiology by 0 . A. Trowell is an excellent review; it is both critical and complete. The contribution by Frederick K. Bang on the effects of invading organisms on cells and tissues in culture also provides an extensive discussion of the different parasitic agents in tissue culture. The following article by Fred Rapp and Joseph L. Melnick is a useful complementary outline of the more technical aspects of the same topic. Nossal's article on antibody production in tissue culture, and Rosenoer and Jacobson's discussion of tissue culture in pharmacology, are useful in bringing together pertinent information from two dispersed fields.

Next comes a short section on the rapidly developing field of invertebrate tissue and organ culture by Bryn M. Jones; this is a good comprehensive account.

The last four chapters comprise, in effect, a small text-book of plant tissue culture. They are authoritative, up to date, and clearly written. The names of the contributors-Street, Henshaw, Braun and Iipetzspeak for themselves.

JoHN PAUI

\title{
Applied Sclence
}

\section{POLLUTING THE ENVIRONMENT}

\section{Organic Pesticides in the Environment}

(Advances in Chemistry Series No. 60.) Edited by Robert F. Gould. Pp. $x+309$. (Washington, D.C.: American Chemical Society, 1966.) $\$ 8.50$.

UHEMICAL pesticides are unique among the many contaminants of the environment, including the motor car and detergents, in that their method of use consists of distributing them in that environment. The problem of posticides in foodstuffs has long been recognized and has been studied at length and in detail; the distribution and fate of the pesticides in the environment have not yet been so extensively studied, but considerable data have been accumulated. The symposium, the contributions to which are included in this volume, dealt with the non-food aspects of pesticides in the environment.

The subject is of topical interest to scientists and lay. men. The symposium attracted original and review papers covering the use of pesticides; methods for detecting their presence and determining the quantities present; their movement in the environment; their fate in soil, water, air, plants and animals. Twenty-three well documented contributions are included in a volume which is well indexed and contains very few errors.
Although a few of the papers will be of intorest only to chemists, many of them will appeal to biologists, agriculturists, spray contractors, and naturalists. They should be read by all with an interest in the land and in atmospheric pollution. The papers aro meaty and cannot be skimmed over; they contain references to practically every aspect of the subject and many interesting facts. For example, the total world production of DDT up to the end of 1965 was about $3,500,000,000 \mathrm{lb}$.-practically $1 \mathrm{lb}$. for every living person. Spread over the Earth's land surface it would give a "deposit" of less than $20 \mathrm{mg} / \mathrm{m}^{2}$.

This is an interesting and very useful book of reference. R. A. E. Galiey

\section{THE UNWILLING HOST}

Textbook of Veterinary Clinical Parasitology

By E. J. L. Soulsby. Vol. 1: Helminths. Pp. xxxi+ 1120. (Oxford: Blackwell Scientific Publications, 1965.) 1898. net.

"ThE purpose of this book is to present an up-to-date account of the clinical and pathological aspects of the helminth infections in domestic animals". The author 